\title{
Immunological comparison of patients with rheumatoid arthritis with and without nephropathy
}

\author{
M Korpela, J Mustonen, H Helin, A Pasternack
}

\begin{abstract}
Serum immunoglobulins IgG, IgA, and IgM, serum complement components $\mathrm{C} 3$ and $\mathrm{C4}$, circulating immune complexes, antinuclear antibodies, and rheumatoid factor were measured in 56 patients with rheumatoid arthritis (RA) and nephropathy (23 with mesangial glomerulopathy; 13 with membranous glomerulonephritis; and 20 with amyloidosis) and 35 patients with RA without nephropathy (controls). Renal immunofluorescence findings in patients with mesangial glomerulopathy were compared with the serologic data.
\end{abstract}

There were no differences in the occurrence of rheumatoid factor, antinuclear antibodies, and circulating immune complexes and the concentrations of serum complement $\mathrm{C} 3$ and C4 between various RA nephropathy groups and controls. Serum IgA and IgM concentrations were significantly higher in patients with mesangial glomerulopathy and amyloidosis than in controls. In patients with mesangial glomerulopathy glomerular IgM, IgA, and C3 were the most prominent findings in immunofluorescence examination. The serum IgA concentration was significantly higher in those patients with mesangial glomerulopathy with mesangial IgA deposits than in those without (4.97 (SD 1.03) $\mathrm{g} / 1 \mathrm{l} 2.07(1.21) \mathrm{g} / \mathrm{l})$. The highest serum IgA concentrations $\mathbf{5 . 0 8}$ $(1.39) \mathrm{g} / \mathrm{l})$ were seen in the four patients with IgA glomerulonephritis. The prevalence of IgA glomerulonephritis in the renal biopsy material of the patients with RA was $5 \%$, which possibly differs little from that seen in the general population.

The results suggest that circulating immune complexes may not have any major role in the pathogenesis of various nephropathy types in patients with RA, contrary to their role in most extra-articular manifestations of RA.

Department of Clinical Sciences, University of Tampere, Finland

M Korpela

J Mustonen

A Pasternak

Department of

Biomedical Sciences,

University of Tampere,

Finland

H Helin

Correspondence to:

Dr Markku Korpela,

Department of Clinica

Sciences, University of

Tampere, Teiskontie 35

SF-33520 Tampere, Finland.

Accepted for publication

6 June 1989

Extra-articular manifestations of rheumatoid arthritis, such as nodules, cutaneous vasculitis, neuropathy, and Felty's syndrome, have been associated with the presence of rheumatoid factor, ${ }^{1}$ circulating immune complexes, ${ }^{2}$ and hypocomplementaemia. ${ }^{3}{ }^{4}$ Deposits of immunoglobulins and complement have been detected by immunofluorescence in skin ${ }^{5}$ and renal ${ }^{7-10}$ biopsy specimens.

Renal amyloidosis and gold or D-penicillamine induced membranous glomerulonephritis are the most well known renal abnormalities in patients with theumatoid arthritis (RA). In more recent studies using immunofluorescence and electron microscopy ${ }^{7-9} 1112$ a mild mesangial glomerulopathy has been a common renal biopsy finding. The aetiology of mesangial glomerulopathy in patients with RA is uncertain, but it has in some cases been associated with gold treatment. ${ }^{713}$ Membranous and mesangial glomerulonephritis are both regarded as immune complex glomerulonephritis. ${ }^{13}$

The purpose of this study was to evaluate some immunological indices of patients with RA with various types of nephropathy and to compare them with values for patients with $R A$ having no clinical renal disease.

Patients and methods

PATIENTS

The patients were selected from those who had undergone renal biopsy at Tampere University Central Hospital between 1976 and 1987. The total number of renal biopsies was 1319 and at the time of renal biopsy 74 patients were diagnosed as having definite or classic RA according to the criteria of the American Rheumatism Association. ${ }^{14}$ The renal biopsy specimens were examined by light, immunofluorescence, and electron microscopy as previously described. ${ }^{15}$

Table 1 shows the renal biopsy findings. The most common nephropathy types were mesangial glomerulopathy, defined by Helin et al, ${ }^{7}$ in 23 patients, membranous glomerulonephritis in 13, and amyloidosis in 20 patients. These three nephropathy groups $(n=56)$ were included in this study. Other renal biopsy findings were seen in only a few cases each and were excluded.

Consecutive inpatients with RA with duration of disease of four years or more were selected as a control group $(n=35)$. Twenty patients in the group with nephropathy and

Table 1: Renal biopsy findings in 74 patients with rheumatoid arthritis and nephropathy

\begin{tabular}{|c|c|}
\hline Renal biopsy finding & $\begin{array}{l}\text { Number } \\
\text { of patients }\end{array}$ \\
\hline $\begin{array}{l}\text { Mesangial glomerulopathy* } \\
\text { Amyloidosis† } \\
\text { Membranous glomerulonephritis* } \\
\text { Diabetic glomerulosclerosis } \\
\text { Focal necrotising glomerulonephritis } \\
\text { Acute destructive interstitial nephritis } \\
\text { Acute tubulointerstitial nephritis } \\
\text { Chronic interstitial nephritis } \\
\text { Myeloma kidney with amyloidosis } \\
\text { Arteriolosclerosis } \\
\text { Normal histology }\end{array}$ & $\begin{array}{r}23 \\
20 \\
13 \\
3 \\
1 \\
1 \\
1 \\
1 \\
1 \\
1 \\
7\end{array}$ \\
\hline
\end{tabular}

Normal histolosis

Non-diagnostic specimen

* Two patients with mesangial glomerulopathy and one with memo patients with mesangial glomerulopathy and one with membranous glomerulonephritis also had vascular amyloidosis. tGlomerular 
seven in the control group were men $(36 \% v$ $20 \%$ ). The ages of the patients ranged from 23 to 73 years (median 51) in the nephropathy group and from 30 to 73 years (median 53) in the controls. The median duration of RA was 11 years (range 1-36) and 12 years (range 4-38) respectively. The stage of radiological progression and class of functional capacity ${ }^{16}$ were also comparable in both groups. Non-renal extraarticular manifestations, including rheumatoid nodules, vasculitis, pulmonary fibrosis, pleuritis, Sjögren's syndrome, polyneuropathy, and episcleritis occurred in 17 patients $(30 \%)$ in the nephropathy group and in 16 patients in the controls (46\%).

The patients in the nephropathy and control groups (56 $v 35$ patients) were treated with sodium aurothiomalate (45 $v 34$ patients), with D-penicillamine (10 $v 12$ patients), with antimalarial drugs (43 $v 23$ patients), with auranofin (one $v$ no patients), with peroral corticosteroids (33 $v 18$ patients), and with cytotoxic drugs (five $v$ two patients). All patients had received nonsteroidal anti-inflammatory drugs. Analgesic abuse was noted in one patient with mesangial glomerulopathy and vascular amyloidosis.

\section{LABORATORY TESTS}

Rheumatoid factor was determined by the latex fixation and Waaler-Rose tests. ${ }^{17}$ Antinuclear antibodies were studied by indirect immunofluorescence with rat liver and kidney as antigens. ${ }^{18}$ Serum immunoglobulins IgG, IgA, and IgM, and serum complement $\mathrm{C} 3$ and $\mathrm{C} 4$ concentrations were measured by laser nephelometry. Circulating immune complexes were assayed by a solid phase $\mathrm{Clq}$ enzyme linked immunosorbent assay (ELISA) ${ }^{19}$ and a platelet aggregation test using radioiodinated protein $\mathrm{A}$ to show platelet bound IgG (PIPA). ${ }^{20}$

Serological analysis was carried out on serum samples taken at the time of renal biopsy (patients with nephropathy) or at the time of clinical study (controls). Serum samples were stored at $-70^{\circ} \mathrm{C}$.

\section{STATISTICS}

Statistical evaluation was performed by Student's $t$ test, $\chi^{2}$ test, Fisher's exact test, and linear regression analysis, as appropriate.

\section{Results}

There were no differences in the occurrence of rheumatoid factor (described earlier in detail by Helin $e t a l^{21}$ ), circulating immune complexes (table 2), antinuclear antibodies, or the concentrations of serum $\mathrm{C} 3$ and $\mathrm{C} 4$ between the various nephropathy groups and the controls.

Table 3 shows the serum immunoglobulin concentrations in various RA nephropathy groups and in control patients. Mean serum IgA and IgM were significantly higher $(p<0.001)$ in patients with mesangial glomerulopathy and amyloidosis than in controls. In patients with mesangial glomerulopathy the mean serum IgA and IgM concentrations were significantly higher $(\mathrm{p}<0.001$ and $\mathrm{p}<0.01$ respectively) than in the group with membranous glomerulonephritis. Mean serum IgG concentrations were significantly lower in all nephropathy groups than in controls.

Table 2: Circulating immune complexes in patients with rheumatoid arthritis with and without nephropathy. No (\%) of patients is shown

\begin{tabular}{|c|c|c|c|c|}
\hline \multirow[t]{2}{*}{ Test } & \multicolumn{3}{|c|}{ Type of nephropathy } & \multirow{2}{*}{$\begin{array}{l}\text { Controls } \\
(n=35)\end{array}$} \\
\hline & $\begin{array}{l}\text { Mesangial } \\
\text { glomerulopathy } \\
(n=22)\end{array}$ & $\begin{array}{l}\text { Membranous } \\
\text { glomerulonephritis } \\
(n=13)\end{array}$ & $\begin{array}{l}\text { Amyloidosis } \\
(n=19)\end{array}$ & \\
\hline $\begin{array}{l}\text { Clq IgG } \\
\text { Clq IgM } \\
\text { PIPA* } \\
\text { Any test }\end{array}$ & $\begin{array}{r}10(45) \\
5(23) \\
15(68) \\
16(73)\end{array}$ & $\begin{array}{r}6(46) \\
3(23) \\
9(69) \\
10(77)\end{array}$ & $\begin{array}{r}7(37) \\
4(21) \\
11(58) \\
11(58)\end{array}$ & $\begin{array}{l}13(37) \\
10(29) \\
17(49) \\
21(60)\end{array}$ \\
\hline
\end{tabular}

*Platelet aggregation test using radioiodinated protein $\mathrm{A}$.

Table 3: Serum immunoglobulin concentrations in patients with rheumatoid arthritis with $(n=56)$ and without (n=35) nephropathy. Values are means (SD)

\begin{tabular}{|c|c|c|c|c|}
\hline \multirow{2}{*}{$\begin{array}{l}\text { Serum } \\
\text { immunoglobulin }\end{array}$} & \multicolumn{3}{|c|}{ Type of nephropathy } & \multirow{2}{*}{$\begin{array}{l}\text { Controls } \\
(n=35)\end{array}$} \\
\hline & $\begin{array}{l}\text { Mesangial } \\
\text { glomerulopathy } \\
(n=23)\end{array}$ & $\begin{array}{l}\text { Membranous } \\
\text { glomerulonephritis } \\
(n=13)\end{array}$ & $\begin{array}{l}\text { Amyloidosis } \\
(n=20)\end{array}$ & \\
\hline $\operatorname{IgG}(\mathrm{g} / \mathrm{l})$ & $14 \cdot 5(4 \cdot 5)$ & $14.4(6.4)$ & $11 \cdot 4(6 \cdot 5)$ & $16.0(6.5)$ \\
\hline $\operatorname{IgA}(\mathrm{g} / \mathrm{l})$ & $3 \cdot 16(\underbrace{1 \cdot 72})$ & $2.08(0.93)$ & $3.08(1.55)$ & $1.95(1.63)$ \\
\hline $\operatorname{IgM}(g / \mathbf{l})$ & $1.93(1.03)$ & $1.52(0.97)$ & $1.88(0.84)$ & $1.28(0.94)$ \\
\hline
\end{tabular}


Table 4: Correlation of serum immunoglobulins $\operatorname{IgG}, \operatorname{IgA}$, and IgM with age, duration of disease, erythrocyte sedimentation rate (ESR), serum protein concentration, and degree of proteinuria in patients with rheumatoid arthritis with $(n=56)$ and without nephropathy $(n=35)$ in linear regression analysis

\begin{tabular}{|c|c|c|c|}
\hline & \multicolumn{3}{|c|}{ Correlation coefficient } \\
\hline & Serum IgG & Serum IgA & Serum IgM \\
\hline $\begin{array}{l}\text { Mesangial glomerul } \\
\text { Age } \\
\text { Duration of RA } \\
\text { Serum protein } \\
\text { Proteinuria } \\
\text { ESR }\end{array}$ & $\begin{array}{l}\text { NS } \\
\text { NS } \\
0 \cdot 833^{* * *} \\
-0.484^{*} \\
\text { NS }\end{array}$ & $\begin{array}{l}0.524^{* *} \\
0.634^{* * *} \\
\text { NS } \\
\text { NS } \\
\text { NS }\end{array}$ & $\begin{array}{l}\text { NS } \\
\text { NS } \\
\text { NS } \\
\text { NS } \\
\text { NS }\end{array}$ \\
\hline $\begin{array}{l}\text { Amyloidosis }(n=20) \\
\text { Age } \\
\text { Duration of RA } \\
\text { Serum protein } \\
\text { Proteinuria } \\
\text { ESR }\end{array}$ & $\begin{array}{l}-0.571^{* *} \\
\text { NS } \\
0.824^{* * *} \\
-0.496^{*} \\
-0.465^{*}\end{array}$ & $\begin{array}{l}\text { NS } \\
\text { NS } \\
\text { NS } \\
\text { NS } \\
\text { NS }\end{array}$ & $\begin{array}{l}\text { NS } \\
\text { NS } \\
\text { NS } \\
\text { NS } \\
\text { NS }\end{array}$ \\
\hline $\begin{array}{l}\text { Membranous glome } \\
\text { Age } \\
\text { Duration of RA } \\
\text { Serum protein } \\
\text { Proteinuria } \\
\text { ESR }\end{array}$ & $\begin{array}{l}\text { NS } \\
\text { NS } \\
0 \cdot 823^{* * *} \\
\text { NS } \\
\text { NS }\end{array}$ & $\begin{array}{l}\text { NS } \\
\text { NS } \\
\text { NS } \\
\text { NS } \\
\text { NS }\end{array}$ & $\begin{array}{l}\text { NS } \\
\text { NS } \\
\text { NS } \\
\text { NS } \\
\text { NS }\end{array}$ \\
\hline $\begin{array}{l}\text { Controls }(n=35) \\
\text { Age } \\
\text { Duration of RA } \\
\text { Serum protein } \\
\text { ESR }\end{array}$ & $\begin{array}{l}\text { NS } \\
\text { NS } \\
0 \cdot 711^{* * *} \\
0 \cdot 375^{*}\end{array}$ & $\begin{array}{l}\text { NS } \\
\text { NS } \\
\text { NS } \\
\text { NS }\end{array}$ & $\begin{array}{l}\text { NS } \\
\text { NS } \\
\text { NS } \\
0 \cdot 435^{* *}\end{array}$ \\
\hline
\end{tabular}

${ }^{*} 0.01<\mathrm{p}<0.05 ;{ }^{* *} 0.001<\mathrm{p}<0.01 ;{ }^{* * *} \mathrm{p}<0.001 ; \mathrm{NS}=$ not significant.

Immunofluorescence microscopy findings were available in 19 out of 23 patients with mesangial glomerulopathy. The most prominent mesangial immunofluorescence deposits were granular $\operatorname{IgA}(n=8), \operatorname{IgM}(n=15)$, and C3 $(n=8)$, whereas $\operatorname{IgG}(n=3)$ and $\mathrm{Clq}(n=1)$ were not often seen. Serum IgM, rheumatoid factor positivity, circulating immune complexes, and complement concentrations did not correlate with mesangial C3 deposits. Neither was there correlation between serum C3 concentration and mesangial C3 deposits.

Eight out of 19 patients with mesangial glomerulopathy had mesangial IgA deposits in immunofluorescence examination. In four patients the finding could be classified as IgA glomerulonephritis, because the main glomerular immunofluorescence finding in their biopsy specimens was diffuse and global IgA. ${ }^{22}$ Patients with mesangial glomerulopathy with mesangial IgA deposits had significantly $(\mathrm{p}<0.001)$ higher serum IgA concentrations $(4.97($ SD 1.03) g/l) than similar patients without IgA deposits $(2 \cdot 07(1 \cdot 21) \mathrm{g} / \mathrm{l})$ or controls $(1.95(1.63) \mathrm{g} / \mathrm{l})$. Serum IgA concentration was highest in the four patients with IgA glomerulonephritis $(5.08(1.39) \mathrm{g} / \mathrm{l})$. Patients with mesangial glomerulopathy had significantly higher $(\mathrm{p}<0.001)$ serum IgA concentrations than the controls $(2.92(1.68) v 1.95(1.63) \mathrm{g} / \mathrm{l})$ even if the four patients with IgA glomerulonephritis were excluded from the group. The occurrence of rheumatoid factor positivity, circulating immune complexes, and serum complement concentrations did not differ in patients with mesangial glomerulopathy with or without IgA deposits.

Serum IgG but not serum IgA and IgM concentrations correlated positively with the serum protein concentration in all nephropathy groups and in the controls. In the patients with mesangial glomerulopathy and amyloidosis, but not in the patients with membranous glomerulonephritis, serum IgG correlated negatively with the degree of proteinuria (table 4). In the control patients serum IgG and IgM concentrations correlated positively with erythrocyte sedimentation rate-a finding not seen in the nephropathy groups. In patients with mesangial glomerulopathy the serum IgA concentration correlated with the patient's age and duration of RA (table 4). In the group with mesangial glomerulopathy the mean serum IgA concentration was significantly $(p<0.05)$ higher in eight patients with non-renal extra-articular manifestations than in 15 patients without $(4 \cdot 17$ $(1 \cdot 81)$ v 2.62 (1.44) g/l). Serum immunoglobulin concentrations did not correlate with articular index, progression stage, or functional capacity.

Membranous glomerulonephritis was clinically associated with parenteral gold or Dpenicillamine treatment in 12 out of 13 cases. In the patients with mesangial glomerulopathy clinical renal disease was detected during parenteral gold, auranofin, and D-penicillamine treatment in 12 out of 23 cases, while six of these patients had not received these antirheumatic drugs. There were no significant differences in age and sex of the patients or in the duration and progression stage of RA between those patients with mesangial glomerulopathy treated with gold or D-penicillamine $(n=17)$ and those untreated $(n=6)$. Moreover, there were no differences in serum immunoglobulin IgG, IgA, and IgM concentrations between these groups.

\section{Discussion}

It has been a general conception that there are no specific rheumatoid lesions in renal tissue and that most renal diseases in patients with RA can be accounted for by amyloidosis, gold nephropathy, chronic pyelonephritis, or analgesic induced nephropathy. ${ }^{23}$ In recent 
renal biopsy studies with electron microscopy and immunofluorescence a mild mesangial proliferative glomerulonephritis has been a common finding in patients with RA with haematuria or proteinuria. $^{7-9} 11$

In our patients membranous glomerulonephritis was strongly associated with gold or Dpenicillamine treatment, as is the general experience. ${ }^{13}$ Gold nephropathy has been regarded as a prototype of membranous glomerulonephritis, ${ }^{24}$ but it has been suggested that mesangial glomerulonephritis is another immune complex glomerulonephritis associated with gold treatment. ${ }^{25}$ The association between gold treatment and clinical renal disease was difficult to ascertain because almost all patients with RA in the nephropathy and control groups had received such treatment. Interestingly, six patients in the group with mesangial glomerulopathy had not been treated with gold or Dpenicillamine, which supports the views of Hordon $e t a l^{11}$ and Sellars $e t a l^{9}$ that in addition to gold or D-penicillamine treatment other factors must contribute to renal injury in patients with mesangial glomerulopathy with RA.

Extra-articular manifestations of RA are generally associated with rheumatoid factor positivity, circulating immune complexes, and hypocomplementaemia. ${ }^{1-4}$ In our patients there were no differences in the occurrence of rheumatoid factor, circulating immune complexes, and the concentrations of $\mathrm{C} 3$ and $\mathrm{C} 4$ between the various RA nephropathy groups and controls. This suggests that in patients with RA circulating immune complexes may not play any major part in renal injury despite the detection of granular deposits of immunoglobulins in the glomeruli of patients with mesangial glomerulopathy and membranous glomerulonephritis. In situ immune complex formation has been found to be an important mechanism in the genesis of subepithelial deposits, ${ }^{26}$ but it is not clear whether this also applies to the subendothelialmesangial site. ${ }^{27}$

Low serum IgA concentrations have been found in patients with RA with gold induced toxic effects. ${ }^{28}$ Here no such observation was made. The mean serum IgA concentration in the group with membranous glomerulonephritis was not different from that in controls. Among the patients with mesangial glomerulopathy there was no difference in mean serum IgA concentration between the gold treated and untreated groups.

In patients with mesangial glomerulopathy and amyloidosis serum IgA and IgM concentrations were significantly higher than in the controls. High serum IgA and IgM concentrations have been found in patients with RA. ${ }^{29-31}$ Serum IgM and especially IgA concentrations have been found to be high in patients with rapidly progressing RA. ${ }^{30}$ Pillemer et al recently showed that total serum IgA and polymeric IgA concentrations are raised in $23 \%$ and $11 \%$ of patients with RA respectively. ${ }^{32}$ Immunological similarities in patients with RA-namely, those with mesangial glomerulopathy and amyloidosis, are difficult to explain, but there may be common pathogenetic factors that contribute to the development of these two conditions. Serov et al postulated a specific rheumatoid nephropathy that may precede renal amyloidosis. ${ }^{33}$ Careful prospective follow up studies are needed in patients with RA with mesangial glomerulopathy because the natural course and significance of the condition are unknown.

In this study high serum IgA concentrations correlated significantly with mesangial IgA deposits in patients with RA with mesangial glomerulopathy. In these patients the mean serum IgA concentration correlated positively with the age of the patient, duration of rheumatoid arthritis, and non-renal extra-articular manifestations. Possibly the high serum IgA concentrations detected in the four patients with IgA glomerulonephritis might have contributed to their mesangial injury. Serum IgA concentration has been found to be high in half of the patients with idiopathic or primary $\operatorname{IgA}$ glomerulonephritis. ${ }^{22} 34$

Although the HLA-DR4 antigen has been shown to associate strongly with IgA glomerulonephritis ${ }^{35} 36$ and also with RA, ${ }^{37} 38$ only a few associations between these two diseases have been reported. Beaman et al described four patients with seropositive RA and IgA glomerulonephritis. ${ }^{39}$ Among 132 patients with RA recently described by Sato et al, 14 had haematuria or proteinuria, or both, and two of these had IgA glomerulonephritis. ${ }^{40}$ In our renal biopsy material the prevalence of IgA glomerulonephritis was $5 \%$, which possibly differs little from that seen in the general population. Sinniah found mesangial IgA deposits in eight out of 200 consecutive necropsies of patients who had died from traumatic injuries. ${ }^{41}$ Similar results have also been obtained in our own necropsy studies (unpublished observation).

In conclusion, immunological comparison between patients with RA with various forms of nephropathy and those without clinical renal disease gave negative results in most indices studied (serum rheumatoid factor, antinuclear antibodies, circulating immune complexes, complement $\mathrm{C} 3$ and $\mathrm{C} 4$ ). The only differences were seen in serum immunoglobulin concentrations. Estimation of the prevalence and significance of mesangial glomerulopathy and $\operatorname{IgA}$ glomerulonephritis in patients with RA would require a prospective population study in which the findings in patients with RA were compared with those found in controls matched for age and sex.

1 Jakle C, Feigal D W, Robbins D L, Shapiro R, Wiesner K. Serum IgG and IgM rheumatoid factors and complement activation in extraarticular rheumatoid disease. $\mathcal{F}$ Rheumato 1985; 12: 227-32.

2 Zubler R H, Nydegger U, Perrin L H, et al. Circulating and intra-articular immune complexes in patients with rheumatoid arthritis. F Clin Invest 1976; 57: 1308-19.

3 Jans H, Halberg P, Lorenzen I. Circulating immune complexes in rheumatoid arthritis with extra-articular manifestations. Scand $\mathcal{I}$ Rheumatol 1983; 12: 215-8.

4 Franco A E, Schur P H. Hypocomplementemia in theuma toid arthritis. Arthritis Rheum 1971; 14: 231-8.

5 Ullman S, Hoier-Madsen M, Halberg P, Jans H, Sylvest J. Deposits of immunoglobulins and complement in skin of Deposits of immunoglobulins and complement in skin of patients with rhe

6 Fitzgerald O M, Barnes L, Woods R, McHugh L, Barry C, O'Loughlin $S$. Direct immunofluorescence of normal skin in rheumatoid arthritis. $B r \mathcal{F}$ Rheumatol 1985; 24: 340-5. 7 Helin H, Korpela M, Mustonen J, Pasternack A. Mild mesangial glomerulopathy-a frequent finding in rheuma- 
toid arthritis patients with hematuria or proteinuria. Nephron 1986; 42: 224-30.

8 Ørjavik O, Brodwall E K, Øystese B, Natvik J B, Mellbye $O \mathrm{~J}$. A renal biopsy study with light and immunofluorescent microscopy in rheumatoid arthritis. Acta Med Scand 1981; microscopy in rhe

9 Sellars L, Siamopoulos K, Wilkinson R, Leohapand T, Morley A R. Renal biopsy appearances in rheumatoid disease. Clin Nephrol 1983; 20: 114-20.

10 Skrifvars B. Immunofluorescence study of renal biopsies in chronic rheumatoid arthritis. Scand $\mathcal{F}$ Rheumatol 1979; 8: 241-7.

11 Hordon L D, Sellars L, Morley A R, Wilkinson R Thompson M, Griffiths I D. Haematuria in rheumatoid arthritis: an association with mesangial glomerulonephritis. Ann Rheum Dis 1984; 43: 440-3.

12 Salomon M I, Gallo G, Poon T P, Goldblat M V, Tchertkoff $V$. The kidney in rheumatoid arthritis. Nephron 1974; 12: 297-310.

13 Hall C L. Gold and D-penicillamine induced renal disease. In: Bacon P A, Hadler N M, eds. The kidney and rheumatic disease. London: Butterworth, 1982: 246-66.

14 Ropes M W, Bennett G A, Cobb S, Jacox R, Jessar R A. 1958 Revision of diagnostic criteria for rheumatoid arthritis. Bull Rheum Dis 1958; 9: 175-6.

15 Helin H, Mustonen J, Pasternack A, Antonen J. IgM associated glomerulonephritis. Nephron 1982; 13: 11-16.

16 Steinbrocker O, Traeger C H, Batterman R C. Therapeutic criteria in rheumatoid arthritis. $\mathcal{F A M A} 1949 ; 140$ : 659-62.

17 Froelich $\mathrm{C}$, Williams $\mathrm{R}$. Tests for detection of rheumatoid factors. In: Rose $\mathrm{N} \mathrm{R}$, Friedman $\mathrm{H}$, eds. Manual of clinical
immunology. Washington: American Society of Microimmunology. Washingt
biology, 1980: $871-3$.

18 Fritzler $M$. Fluorescent antinuclear antibody test. In: Rose N R, Friedman H, eds. Manual of clinical immunolog. Washington: American Society of Microbiology, 1980: 852-7.

19 Ziola B, Salmi A, Penttinen K. Porcine Clq and the solidphase immunoassay of human immune complexes. phase immunoassay of human imm

20 Kekomäki R, Penttinen K. Platelets and 125-I-labelled staphylococcal protein $A$ in the detection of immun complexes in serum. I Clin Lab Immunol 1979; 1: 305-9.

21 Helin H, Korpela M, Mustonen J, Pasternack A. Rheumatoid factor in rheumatoid arthritis associated renal disease and in lupus nephritis. Ann Rheum Dis 1986; 45: 508-11.

22 Mustonen J, Pasternack A, Helin H, Nikkilä M. Clinicopathologic correlations in a series of 143 patients with IgA glomerulonephritis. Am f Nephrol 1985; 5: 150-7.

23 Decker J L, Plotz P H. Extra-articular rheumatoid disease. In: McCarty D J, ed. Arthritis and allied conditions. Philadelphia: Lea and Febiger, 1985: 620-42.

24 Törnroth T, Skrifvars B. Gold nephropathy prototype of membranous glomerulonephritis. Am $\mathcal{F}$ Pathol 1974; 75: 573-90.

25 Blackwell M R, Hall C L, Tribe C R, Bacon P A. Gold induced nephropathy-2 histological types. Ann Rheum Dis 1981; 40: 525 .

26 Couser W G, Salant D J. In situ immune complex formation and glomerular injury. Kidney Int 1980; 17: 1-13.

27 Cameron J S, Clark W F. A role for insoluble antibodyantigen complexes in glomerulonephritis. Clin Nephrol 1982; 18: $55-61$.

28 Van Riel P L, van de Putte L B, Gribnau F W, de Waal R M Serum IgA and gold-induced toxic effects in patients with rheumatoid arthritis. Arch Intern Med 1984; 144: 1401-3.

29 Barden J, Mullinax F, Waller M. Immunoglobulin levels in rheumatoid arthritis: comparison with rheumatoid factor titers, clinical stage and disease duration. Arthritis Rheum 1967; 10: 228-34.

30 Frank O, Klemmauer K. Das Verhalten der Immunglobuline im Serum bei progredient chronischer Polyarthritis in Immunitaetsforschung, Experimentelle und Klinische ImmunoImmunitaetsforschung, Exp

31 Marcolongo R, Carcassi A, Frullini F, Bianco G, Bravi A Levels of serum immunoglobulins in patients with rheuma toid arthritis. Ann Rheum Dis 1967; 26: 412-8.

32 Pillemer S R, Reynolds W J, Yoon S J, Perera M, Newkirk $M$, Klein $M$. IgA related disorders in rheumatoid arthritis. f Rheumatol 1987; 14: 880-6.

33 Serov V V, Tareeva I E, Borisov I A, et al. Rheumatoid nephropathy. Sov Med 1972; 72: 14-18.

34 Clarkson A R, Seymour A E, Chan Y L, Thompson A J Woodroffe A J. Clinical, pathological and therapeutic aspects of IgA nephropathy. In: Kincaid-Smith P, Apice A J, Atkins R C, eds. Progress of glomerulonephritis. New York: Wiley, 1979: 247-59.

35 Hiki Y, Kobayashi Y, Tateno S, Sada M, Kashiwagi N Strong association of HLA-DR4 with benign IgA nephropathy. Nephron 1982; 32: 222-6.

36 Kashiwabara H, Shishido H, Tomura S, Tuchida H, Miyajima T. Strong association between IgA nephropathy and HLA-DR4 antigen. Kidney Int 1982; 22: 377-82.

37 Panayi G, Wooley P, Batchelor J. Genetic basis of rheumatic disease: HLA antigens, disease manifestations and toxic disease: HLA antigens, disease manifestation
reactions to drugs. $\mathrm{Br} \mathrm{Med} \mathcal{F} 1978 ;$ ii: $1326-8$.

38 Stastny P. Association of the B-cell ill $1326-8$. rheumatoid arthritis. $N$ Engl f Med 1978; 298: 869-71.

39 Beaman M, Adu D, Howie A J, McConkey B, Michael J Popert A J. Rheumatoid arthritis and IgA nephropathy. $B$ f Rheumatol 1987; 26: 299-302.

40 Sato M, Kojima H, Koshikawa S. IgA nephropathy in rheumatoid arthritis. Nephron 1988; 48: 169-70.

41 Sinniah R. Occurrence of mesangial IgA and IgM deposits in a control necropsy population. F Clin Pathol 1983; 36: 276-9. 